\title{
The NN's souls-cult: a case study of catholicism and popular religion in Colombia
}

\author{
Luis Bastidas Meneses • Tom Kaden • Bernt Schnettler
}

Received: 1 February 2021 / Revised: 19 July 2021 / Accepted: 27 July 2021 / Published online: 27 August 2021

(C) The Author(s) 2021

\begin{abstract}
This article analyzes the cult of the souls in Purgatory in Puerto Berrío, Colombia, and its relationship with the Catholic Church. Through empirical evidence, it identifies three characteristics of this cult, namely, its relative independence from the Catholic Church, its heterogeneity and its utilitarian character, and compares them with other cases of Latin American popular Catholicism. The particularities of the cult enable an analysis of how popular religion, rather than generating a conflict with the Catholic Church, maintains an ambiguous relationship with it. The case shows that popular religion not only incorporates the symbolic structure of the Catholic Church to legitimize itself, but also that the church tolerates it, contributing to the peaceful coexistence of the popular and the institutionalized. Consequently, this leads believers, instead of adhering to a supposed binary opposition, to shift between popular and institutionalized religion.
\end{abstract}

Keywords Popular Catholicism · Popular religion · Death rituals · Religious change $\cdot$ Religion in Latin America

\section{Introduction}

In this article, we explore a set of popular religious practices and beliefs surrounding the souls of deceased people in Colombia. We investigate the relationship between these beliefs and practices and the larger Colombian religious landscape, in particular institutional Catholicism. We argue that our case, like others across Latin America, is distinct, but not independent from, institutional Catholicism, which is why we

Luis Bastidas Meneses $(\varangle) \cdot$ Tom Kaden $\cdot$ Bernt Schnettler

Faculty of Cultural Studies, Department of Sociology, Chair of Sociology of Culture and Religion,

University of Bayreuth, Gebäude GW II Büro 2.22 Universitätsstr. 30, 95447 Bayreuth, Germany

E-Mail: luis.bastidas@uni-bayreuth.de 
deem it an expression of popular Catholicism. We identify three different aspects of popular Catholicism - relative autonomy, heterogeneity, and utilitarianism - and we exemplify each with regard to the Colombian souls-cult, and also with reference to other Latin American cases.

In terms of our contributions to sociology of religion, with this case study we will shed light on how new social forms of religion can evolve. Particularly, we will focus on the interaction of the institutionalized form of church religion with practices located at the margins, or even outside, of its dogmatic limits. These practices, growing from the grassroots-level, are interacting with the dominant local orthodoxy, in our case the Catholic Church. One could expect several potential reactions by the establishment, ranging from repression and conflict to tolerance or even absorption. In any case, in the long run these interactions, whether they point to extinction of deviant practices or its neutralization by integration, open up opportunities for reshaping the current social form of religion.

This is why this case study may help in understanding religious change. Because whatever else religions are, for the social scientist they are in any case historical entities that are usually based on-sometimes older, sometimes newer-traditions, and which, in one way or another, convey meaning that encompasses more than just one section of the lifeworld. Above all, they are institutionalized, albeit in very different ways, and the social forms of religion differ from epoch to epoch and from culture to culture.

In the case at hand, it is crucial that the initiative to develop ritual innovations regarding the veneration of the deceased arose among the people, from below, disregarding the Catholic Church's established hierarchy. Rooted in local practices of lay women and men, these new rituals count on extensive support from the people. This is why we suggest using the concept of 'popular Catholicism' in order to describe these innovative, nonconforming religious practices and their interlocution with the Church's precepts.

To some extent, our analysis will also contribute to the ongoing debate on popular religion by providing an example from the Global South that may help open the horizon. Without going into details, the concept of 'popular religion' has been used in sociology and the study of religions, in theology and related disciplines, in quite a number of ways. It encompasses interpretations that range from rather orthodox understandings to quite novel conceptualizations. An example for the first is the idea of a religion that "originate[s] within the traditions of common people" (Isambert 1982; Graziano 2007, p. viii), or popular religion as the beliefs and practices of the poor (Parker 1993; Peterson 1998; Scheper 2016). Other scholars refer to the devotion that people cultivate on their own, emphasizing the relative independence of religious practices and belief cultivation from institutional teaching (Delgado 1991; Marzal 2002). In this sense, practices and expressions of popular religion have coexisted with institutionalized religion over centuries, and were either combatted as superstition, misbelief, or heresy, or more or less tolerated as deviant yet acceptable piety, or even integrated into the orthodoxy via syncretism.

Other scholars, departing from these classical understandings that are often biased by an unquestioned predominance of church religion, suggest using popular religion as an innovative theoretical concept in order to highlight more recent developments. 
Paying special attention to the transformation of the social form of religion in late modern societies, the concept has been used as an extension of Thomas Luckmann's theses of pronounced religious individualization, as formulated in the last chapter of his pathbreaking Invisible Religion (1967). Hubert Knoblauch (2009) refers to Popular Religion as a way to theorize the most salient changes in contemporary religion in modern societies. In this process, the role of extraordinary experiences of transcendence acquire widespread significance among believers that gradually become detached from established religious institutions. The result is religious subjectification.

While this resonates with more traditional forms of popular beliefs, Knoblauch's (2008, 2014) concept of popular religion refers to a process of simultaneously shrinking and expanding religion: At the same time as church-based forms of religions are shrinking in parts of Europe, religion expands through the pervasive use or religious symbols in pop culture and the communication of religion through mass media, such as television and the Internet. While this diagnosis may in some sense look similar to what has been termed 'consumer religion' by Adam Possamai (2005), it rejects such pejorative connotation. Knoblauch, instead, contends that through means of popular culture, religion has diffused out of the narrow circle of ecclesiastical and religious institutions into the broader, formerly secular, areas of culture. This process cuts across tradition and modernity, individualization, and collective effervescence (Haken 2020). In short, this concept of popular religion was mainly developed in order to grasp religious transformation in societies in Europe and North America. It remains open to further inquiry how this concept may help to understand processes of religious change going on in other world regions. Our analysis is designed to provide material for subsequent and more systematic comparisons.

Against this backdrop, we accentuate the popular aspect of Latin American popular Catholicism by pointing towards the absence of control by any strong established church religion. This leads to very specific features, such as the development of its own logic reflected in characteristics like the eclectic combinations of beliefs and practices, the ability to adapt to different traditions, a tremendous heterogeneity, and its mundane orientation to generate practical and beneficial result for these who practice it.

In what follows, we briefly sketch our case material before entering into a more detailed exploration of the three characteristics of the souls-cult mentioned above, which characterize it as a form of popular Catholicism. Our conclusion discusses our case as a form of popular Catholicism and its relation to institutional religion.

\section{Case description}

Based on ethnographic observation, supported by interviews and photographs taken in the last quarter of 2019, this article focuses on a case of popular Catholicism, specifically on the cult of the souls in Purgatory in the municipality of Puerto Berrío ${ }^{1}$,

\footnotetext{
1 Located in the southeast of the department of Antioquia, Puerto Berrío has an estimated population of 36,000 inhabitants, according to the 2018 population census (Torres et al. 2020).
} 


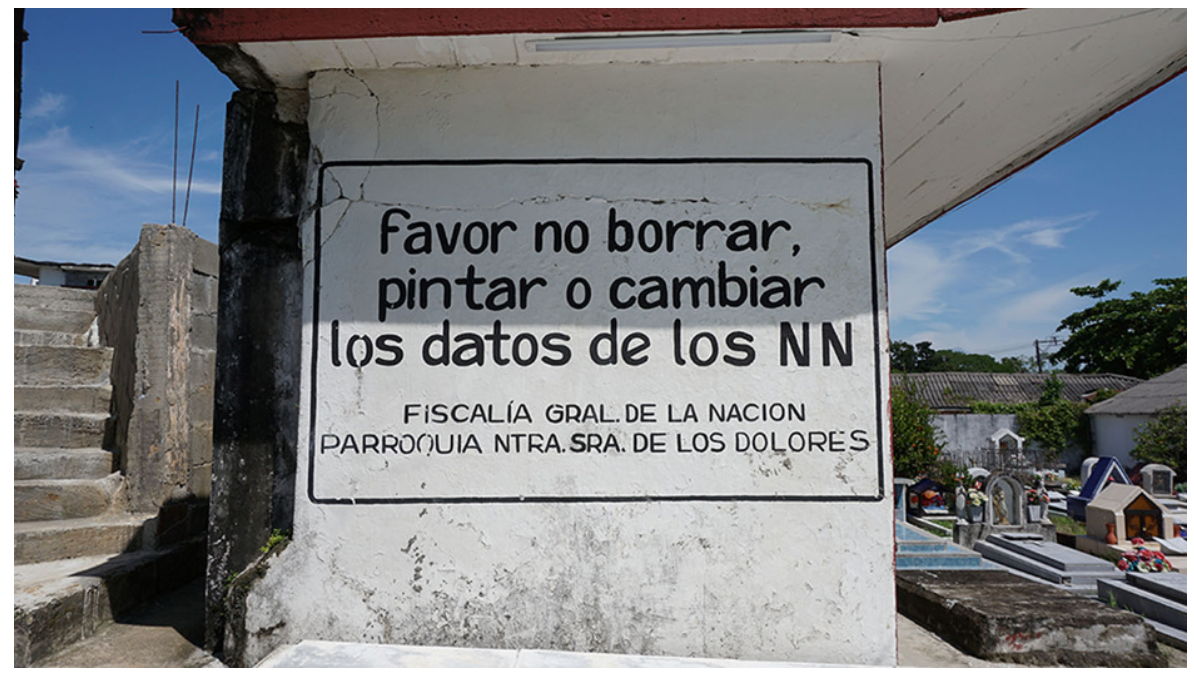

Fig. 1 Cemetery in Puerto Berrío "Please don't erase, overpaint or change the NN's dates. Office of the Attorney General. Our Lady of Sorrows Parish". Photo by Luis Bastidas Meneses, November 2019

on the banks of the Magdalena River, in the Magdalena Medio region, Colombia, which between late 1980s and late first decade of the 2000s was one of the epicenters of the Colombian internal armed conflict ${ }^{2}$.

In Puerto Berrío, some people who self-identify as Catholics make different petitions to the souls of the deceased buried in the municipal cemetery, many of whom are victims of the armed conflict, some of them buried as $\mathrm{NN}^{3}$, as they were found floating in the river. The anonymous corpses used to be taken by Medicina Legal (Legal Medicine) ${ }^{4}$ to the area of the cemetery reserved for the poorest people

\footnotetext{
2 The Colombian armed conflict is the longest internal war in Latin America. It involves the confrontation between left-wing guerrilla groups and the Colombian army since the mid-1960s, and right-wing paramilitary groups since the late-1970s. Over time, the conflict has worsened, leaving thousands of civilian victims and multiple human rights violations by all the armed groups involved. In 2005, the paramilitary United Self-Defense Forces of Colombia (AUC) signed a peace agreement, as did the left-wing guerrilla group Revolutionary Armed Forces of Colombia-People's Army (FARC-EP) in 2016. However, despite the demobilization of powerful armed groups, multiple factors have allowed the conflict to continue and even worsen. See: Mauricio Romero (2003), Historical Memory Group (2016) and Francisco Gutiérrez (2020).

3 An NN-initials stand for Ningún Nombre (No Name) - is a corpse whose identity is unknown, since at the time of its discovery there were no documents or family members, friends, or acquaintances to identify it. The corpses founded in the river are usually of victims of forced disappearance, which, according to the Office of the High Commissioner for Human Rights of United Nations, is "considered to be the arrest, detention, abduction or any other form of deprivation of liberty by agents of the State or by persons or groups of persons acting with the authorization, support or acquiescence of the State, followed by a refusal to acknowledge the deprivation of liberty or by concealment of the fate or whereabouts of the disappeared person, which place such a person outside the protection of the law" (UN Human Rights 2021).

4 This is the short name for the National Institute of Instituto Nacional de Medicina Legal y Ciencias Forenses (Legal Medicine and Forensic Sciences), the Colombian official institution that controls and manages the forensic science system.
} 


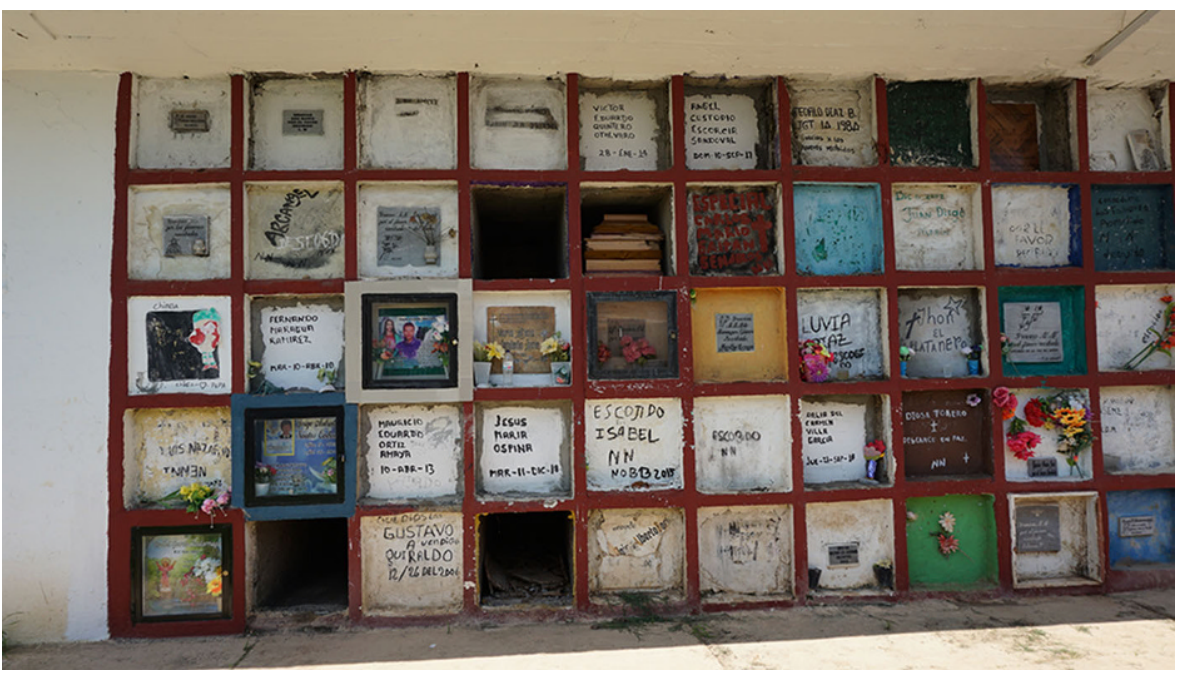

Fig. 2 Some NN's graves in the charity area of the Puerto Berrío cemetery. Photo by Luis Bastidas Meneses, November 2019

(Fig. 1). There, many of the no name graves could be distinguished from others due to plaques expressing gratitude for a miracle or handwritten inscriptions across the rustic surfaces: Escogido (Chosen), which means the NN has been adopted, that is that somebody gave them a name, prays for them and takes care of the tomb-sometimes adorned with some object, e.g. images of the Virgin Mary, angels, crucifixes, and flowers - in exchange for favors requested from the anonymous soul (Fig. 2).

The practice of adopting NNs is underpinned by the belief that the souls of the dead need the prayers of the living to shorten their time in Purgatory. In return, they would reward the prayers with miracles. Since the general belief is that the grave is the house of the soul, many are adorned with photographs, flowers, stamps, images of saints, and elements related to the affinities that the deceased one had in life, such as soccer team logos or miniature cars if the person was a mechanic or a driver. Some are so well maintained that a padlocked glass encloses them, nevertheless, the graves of identified deceased people are more cared for than the ones for the NNs.

These beliefs and practices are reinforced both by Catholic priests and a layman specialist in the cult of the souls called the animero $^{5}$ (souls keeper). Every Monday a crowded Eucharist is held in the cemetery, and throughout November the animero,

\footnotetext{
5 The term animero comes from the Spanish word ánima, which, in Catholic doctrine, refers to a soul that is purifying in purgatory before going to heaven.

6 The novena is a traditional prayer in Catholicism through which devotees, during nine successive days, generally make petitions and implore favors to saints, Jesus Christ, and the Virgin Mary. Saints generally have their own novena with their own exclusive prayers, which in turn refer to specific believers' needs. In Colombia, even the souls in Purgatory have their own novena.
} 


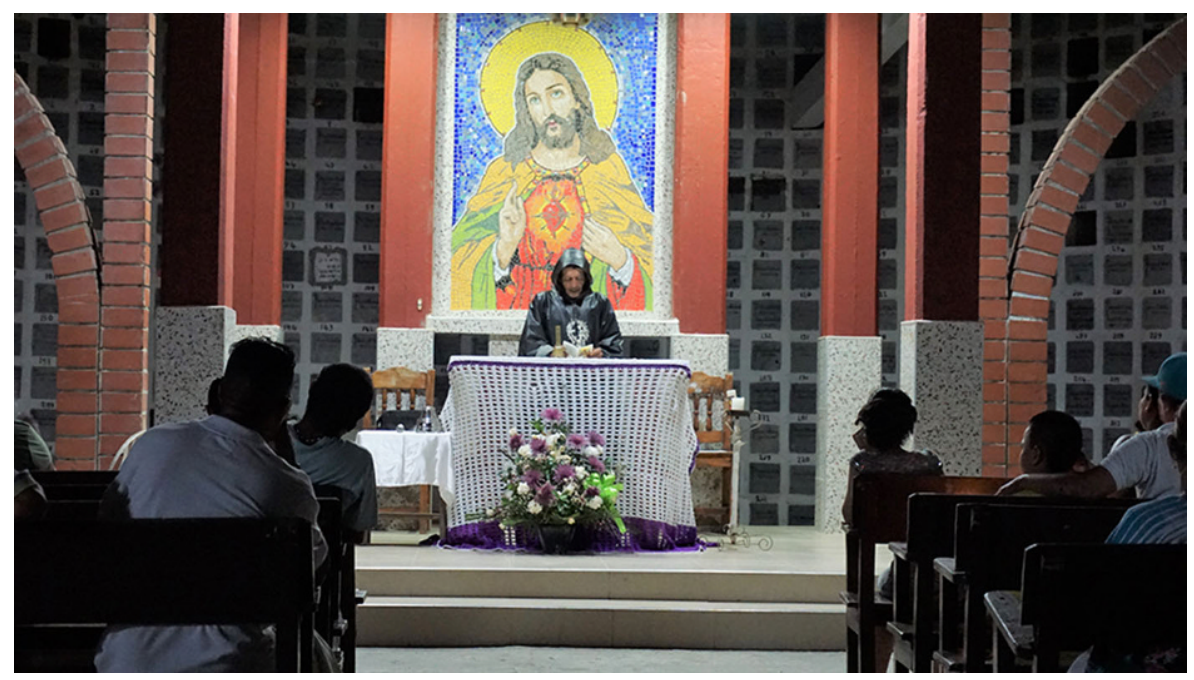

Fig. 3 El animero, Puerto Berrío Cemetery Chapel. Photo by Luis Bastidas Meneses, November 2019

accompanied by believers, prays a novena ${ }^{6}$ to the souls in the cemetery chapel and makes nightly processions through the streets of the town (Fig. 3).

Although the belief in souls in Purgatory is well known in Colombia, the cult of souls, like other popular religious expressions, has not been a recurring theme in the research agenda of the sociology of religion in Colombia since, as we will see below, they have concentrated more on religious diversity understood in terms of the coexistence of the Catholic Church and other Christian churches.

\section{The Colombian religious landscape}

In Colombia, the Catholic Church and other Christian churches, such as Protestant and Pentecostal are the most visible religious organizations. The Catholic Church has been the predominant religious institution since the Spanish colonization, so much so that the political constitution of 1886 declared the Catholic religion as the official religion of the nation and entrusted the church with the teaching of Catholicism in public educational institutions. This close relationship lasted until the proclamation of a new political constitution in 1991, which decreed freedom of worship and recognized the secularity of the Colombian state (Arias 2003; Beltrán 2013). Since the 19th century, Colombia has received frequent visits from North American and European Protestant and Pentecostal missionaries, who initially founded small religious groups, but which grew rapidly by the second half of the 20th century (Thompson 2005; Beltrán 2013). Since the end of the 20th century, due to the new political constitution, many of those Christian churches-specifically Pentecostals - have founded political parties, participated in elections and secured seats in national and regional legislative institutions (Duque 2010; Beltrán and Quiroga 2017; Ortega 2018). 
This dynamic has led studies in Colombia to concentrate on the Christian churches, ultimately paying much less attention to other expressions, such as religions of Eastern or African origin and those framed within so-called popular religion. The idea that the Colombian religious landscape has experienced a Catholic monopoly, challenged by the emergence and expansion of other Christian churches, has been favored. In this vein, publications such as the comprehensive study "From the Catholic Monopoly to the Pentecostal Explosion. Religious Pluralization, Secularization and Social Change in Colombia" (Beltrán 2013) serve as an example 7 .

However, this idea overlooks religious diversity, which is not limited to the coexistence of the Catholic Church with the Protestant and Pentecostal churches. The very few studies that address the religious diversity in Colombia (Beltrán 2012, 2013; Beltrán and Larrota 2020) draw on two elements, consequently enabling the idea of the Catholic monopoly to be questioned: the absence of studies that allow us to compare the diverse present with the past and the approach of religious selfidentification in surveys as an unreliable indicator of Catholicism's role in people's lives.

William Beltrán and Sonia Larrota recognize the absence of studies and data on religious diversity in Colombia, and the focus on the aforementioned religious institutions:

There are no studies that seek to understand the process of religious change in Colombia from a broad perspective. Practically all research is limited to historical or ethnographic case studies on a particular religious organization [...]. Moreover, most of this research lacks a comparative perspective that considers regional diversity and the differences among the various religious movements (Beltrán 2013, p. 22).

Since there are no official numbers to account for this process, characterizing this religious and social transformation-from a quantitative perspective-is a complex undertaking. The most recent census data on religious composition that we have been able to trace dates back to 1938 (De Roux 1983): at that time 99\% of Colombians identified themselves as Catholics ${ }^{8}$ (Beltrán and Larrota 2020, p. 13).

If there are not enough studies and data that address religious diversity in Colombia, beyond the study of the Catholic Church and other Christian churches, why does the idea of a Catholic monopoly persist? And precisely how is the idea of a religious monopoly understood?

According to Alejandro Frigerio (2018), who seeks to explore this critique of Latin American studies in general and in Argentina in particular (Frigerio 2007, 2013, 2018; Frigerio and Wynarczyk 2013), the idea of the Catholic monopoly

\footnotetext{
7 Unlike other classic topics of study in Colombian sociology—such as politics, violence, and the armed conflict-religion has not occupied a central place in the research agenda. In addition, another text that emphasizes the idea of the Catholic monopoly is: "From Catholic monopoly to the establishment of Pentecostalism: changes in Latin American Christianity since the second half of the 20th century" (Bustamante and Orellana 2020).

8 Beltrán had already said something similar in 2012: "there are no reliable figures that allow us to dimension it or observe its trends at the national level” (Beltrán 2012, p. 203).
} 
stems from Latin American scholars' reading of the relationship between religion and modernity in the work of authors such as Peter Berger and Danièle HervieuLéger. Scholars, Frigerio argues, would generally agree that:

through most of human history religious establishments have existed as monopolies in society-monopolies, that is, in the ultimate legitimation of individual and collective life. Religious institutions really were institutions properly speaking, that is, regulatory agencies for both thought and action (Berger 1990, p. 135).

Such legitimation occurs through the construction of a common world (the world) maintained by the mundane institutional powers of control and the "common sense" of the members of society, within which social life has meaning, that is, an objectified order understood as a sacred cosmos (Berger 1990, p. 135). In addition, studies have adopted the idea of secularization proposed by Hervieu-Léger (2005), who understands it as the result of the deconstruction of past forms of solidarity as well as the social breakdown of religious ideals, and defines it as the recomposition of the forms of religiosity, characterized by the individualization of beliefs, religious diversity, and the breakdown of collective memory, rather than the loss of religion.

In this sense, studies have accentuated a hypothetical situation of change that distinguishes between a before-exclusively Catholic — and an after-diversified by the Pentecostal explosion:

Most quantitative research compares the current situation with the supposed past provided by this theoretical perspective. Therefore, the current empirical data are read by comparing them, explicitly or implicitly, with a past determined by the theoretical influence rather than empirical evidence, and what is novel about the current situation is that it concerns a hypothetical past in which Catholicism would seem to function as the sacred canopy of our societies (Frigerio 2018, p. 55).

In addition, quantitative studies have usually taken religious self-identification as a reliable indicator that institutional Catholicism does, indeed, have a determining position in people's lives. However, it is necessary to mention that while most people identify themselves in surveys as Catholic, this corresponds specifically to a question about religious affiliation. It offers very little information about their beliefs, practices, and "the place of being Catholic in their structure of identity commitments and whether this identification has any relevance for their personal identity" (Frigerio 2018 , p. 63). In other words, the data in itself would be "misleading because it hides self-constructed religiosities or spiritualities" (Di Stefano 2013, p. 2), given that in addition to the socially legitimized beliefs and practices of Catholics-practices that are recognized as proper to Catholicism, such as the practice of the sacraments or the belief in the holy trinity-people have often assumed others that transcend the boundaries of the Catholic teachings, as can be seen through the various cases of popular religion in Latin America.

The focus on religious self-identification of the quantitative studies in Colombia, such as those led by William Beltrán (Beltrán 2013; Beltrán and Larrota 2020), does not deny diversity since it recognizes other religious groups than the Christian 
Churches—-for instance, Buddhism, Islam, and Hinduism—and beliefs held without belonging to some group or church, but marginalizes from the study other beliefs and practices than the ones traditionally recognized as religious. This dynamic becomes even more evident if one considers that, as Christian Parker (1993) highlights in his analysis of Latin American Catholicism, many of those who identify themselves as Catholics adopt other beliefs and practices outside the guidance of the institutionalized church and its control. ${ }^{9}$

However, the aforementioned surveys in Colombia raise the question to what extent those who identify themselves as Catholics follow Catholic teachings and practices. In a 2010 survey, although $70 \%$ of the respondents identified themselves as Catholics, $39.1 \%$ of them acknowledged that they did not practice the Catholic religion, and $26.8 \%$ responded that they rarely or never attended a religious ceremony (Beltrán 2013). Likewise, although in the 2019 survey 57.2\% of the respondents identified themselves as Catholics, $46.8 \%$ of them stated that they rarely or never attended a Catholic ceremony ${ }^{10}$ (Beltrán and Larrota 2020).

We acknowledge that quantitative studies on religious diversity in Colombia contribute to a general picture of the composition of the religious landscape through the measurement of religious identifications. This is also true concerning other elements of such identifications, for example sexuality, gender, and political affinities. However, in order to capture religious diversity and complement the image of religious identifications, it is necessary to study beliefs and practices that transcend the teachings of the churches. The surveys we discussed have not-and perhaps cannot-address these sufficiently. For instance, the beliefs and practices of those who in the surveys identify as Catholics, but seem to distance themselves from the Catholic Church.

In what follows, we present the Colombian case of the cult of the souls in Purgatory and point to structural similarities with other examples in Latin America. The case is prominent among the devotions that people adopt beyond the doctrines of religious institutions, in particular those of the Catholic Church. Its analysis indicates directions for scholarship on religion in Colombia, as well as Latin America as a whole, that transcend the limitations described above.

\footnotetext{
9 Something similar can be noted in the case of Pentecostalism. For example, as Susana Andrade (2004) points out, despite the expansion of Pentecostalism among the indigenous communities of Chimborazo, Ecuador, many people keep practices typical of their tradition regardless of whether they were considered sinful by the teachings of foreign evangelical missionaries.

${ }^{10}$ In the 2010 survey, $16.4 \%$ of the Colombians who consider themselves Catholics stated that they attended some Catholic ceremony from time to time, $7.1 \%$ only attended special ceremonies-such as marriages, funerals, baptisms, etc.- and 3.3\% never attended (Beltrán 2013, p. 110). In the 2019 survey, 32\% of the Colombians who consider themselves Catholic stated that they attend some religious ceremony from time to time, $12.8 \%$ that they only attend special ceremonies and $2 \%$ never attend a religious ceremony (Beltrán and Larrota 2020, pp. 96-97).
} 


\section{Characteristics of the cult of the souls in purgatory in Puerto Berrío}

Although popular Catholicism is one expression of the heterogeneous range of Latin American popular religion, "it is necessary to recognize that empirical evidence additionally demonstrates that it is, without doubt, the most generalized and widespread" (Parker 1993, p. 167). In Colombia, this can be observed in different cities and regions through different forms, such as the cult of folk saints ${ }^{11}$ (Losonczy 2001; Vignolo 2013). Here the focus is on the beliefs and practices constituting the religious life of people who identify themselves as Catholics and have adopted the cult of the souls in Purgatory.

\subsection{A religion sui generis}

Perhaps the main characteristic of popular Catholicism is its relative independence from the Catholic Church. It can follow an autonomous development with great capacity for adaptation. In this sense, popular Catholicism includes "a set of ritual acts that have their support in the institutional norms of Catholicism, but which exceed the control of the Church and follow its own logic and development" (Colatarci and Vidal 2008, p. 129). This can be observed through different elements. The first one is the eclectic combinations of beliefs and practices from diverse sources in which people engage (McGuire 2008), which some Latin American scholars such as Manuel Marzal (1993, 2002), Jean Pierre Sanchis (2001) and Renée De la Torre (2013), have referred with the term syncretism ${ }^{12}$.

In Puerto Berrío, the Catholic church plays a fundamental role in this confluence of beliefs and practices, both institutional and popular, because it not only tolerates the cult of the souls, but also promotes and facilitates it. Catholic doctrine commemorates the day of the deceased every November, 2nd, and throughout the month asks Catholics to "honor the memory of the dead and offer prayers in suffrage for them, above all the Eucharistic sacrifice, so that, thus purified, they may attain the beatific vision of God" (Roman Catholic Church 2003). On this subject, it is not surprising that Catholics in Colombia attend the Eucharist, pray the rosary, pray the novena for the souls and practice the sacrament of confession as well as perform Works of Mercy $^{13}$ in the name of penitent souls (Bastidas et al. 2018).

\footnotetext{
11 In view of the variety of practices and beliefs, Jennifer Scheper points out that popular Catholicism "is not in fact singular or homogeneous. Rather, the term encompasses a diversity and myriad of culturally specific local practices, of 'Catholicisms' in the plural”' (Scheper 2016, p. 481).

12 Due to the pejorative implications, the term 'syncretism' has been relatively recently questioned by many scholars (McGuire 2008). For the debate on the use of this term in the Latin American study of religion see De la Torre and Martín (2016).

13 The works of Mercy refer to fourteen actions whose purpose is to help the needy. These "[a]re classified in spiritual Works of Mercy-teach the one who does not know, give good advice to those who need it, correct the erroneous, forgive the insults, comfort the sad, patiently suffer the faults of others, pray to God for the living and lost souls - and corporal Works of Mercy_visiting and caring for the sick, feeding the hungry, giving drink to the thirsty, lodging the pilgrim, dressing the naked, freeing the captive, burying the dead-." (Bastidas 2015, p. 114).
} 
This is followed both by the priests of Puerto Berrío, who invite Catholics in their homilies to pray for the deceased, and by the animero, a layman around 70 years old with no official certified qualification in the administration of salvation goods, who performs specific activities during November ${ }^{14}$.

Every night during November, at approximately 11:00PM, the animero performs a small ceremony in the cemetery chapel. Dressed in a specific outfit consisting of two rosary necklaces wrapped around each arm, a black waterproof poncho with a hood that has the face of Jesus painted in white on the front, and rubber boots. He prays the novena for the souls of Purgatory accompanied by approximately 30 people each night, who then accompany him in processions through different parts of Puerto Berrío. Before going out to the street, he goes through the cemetery praying and ringing a bell to, according to the tradition, call the souls of the deceased who rest there to accompany him in the procession, an activity that he repeats in reverse when the procession ends, returning them to their resting place.

After the prayers, at approximately midnight, the animero begins the procession in which he prays aloud for the souls and rings the bell, announcing each of his prayers: "An Our Father and a Hail Mary for the souls in Purgatory for the love of God!" or "Give them, Lord, eternal rest!", to which the people following him in the procession reply "May perpetual light shine for them!", and he replies "Rest in peace, amen!” (Fig. 4).

These practices, far from fueling conflict with the priests of the two Catholic parishes in Puerto Berrío, are instead supported by them. The priests not only invite Catholics to pray for the dead at the Eucharist celebrated every Monday-since Monday is the day of the dead, according to Catholic tradition-of the year in

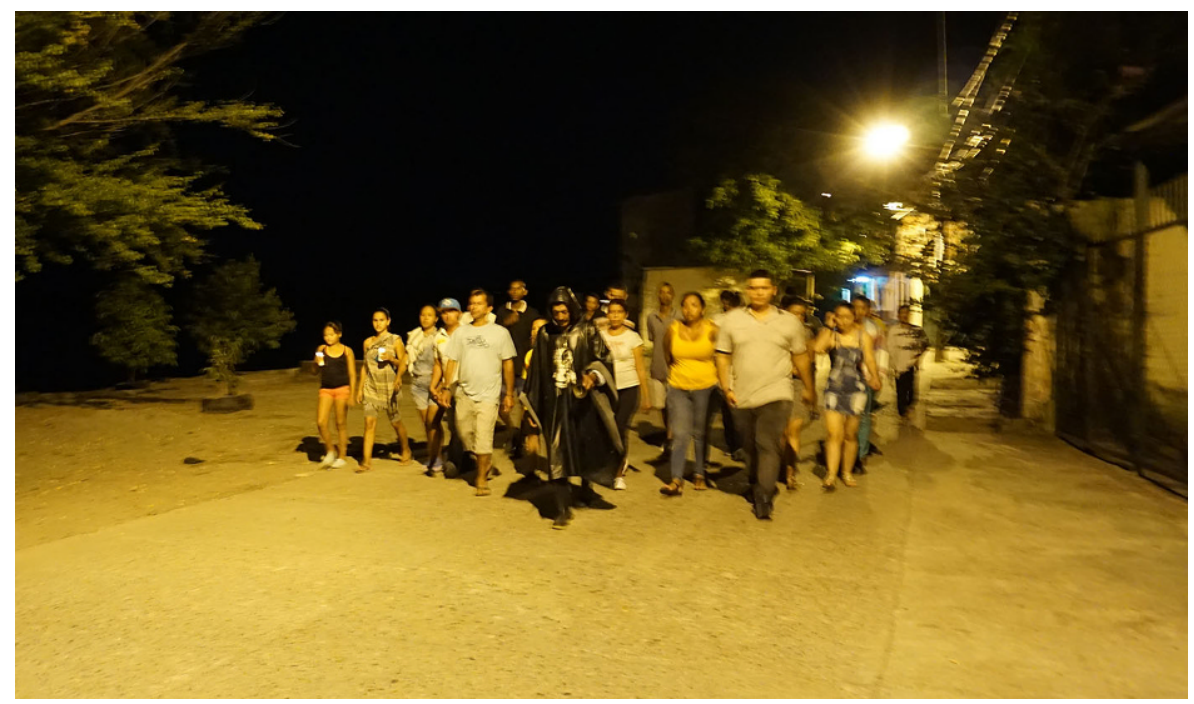

Fig. 4 El animero leading the procession. Photo by Luis Bastidas Meneses, November 2019

14 With other and similar characteristics, the figure of the animero is also present in other towns of the Andean state of Chimborazo, Ecuador. In this regard see: see Arias (2017) y Veloz (2017). 
the cemetery chapel, but they also lend the chapel to the animero to carry out his activities. Additionally, they invite people to pray for the souls in purgatory when they hear the sound of the bell announcing that the night procession is passing by their houses, well aware that people perform certain activities not to commemorate the memory of the deceased, but for magical purposes.

On this subject, one of the priests said:

the animero is a person who invites others to pray for the souls, I can say that in the month of November there is a person who goes through the neighborhoods of Puerto Berrío, ringing a bell so that people realize that at that moment he is passing by, inviting them to pray an Our Father and a Hail Mary for the souls in Purgatory, (...) it helps faith, doesn't it? Because anyway, as you see, he is inviting them to pray, and that is what people do at home, pray (Interview. November 5th, 2019).

In Puerto Berrío many believers mix both institutional and popular beliefs and practices. Some attend the Catholic Eucharist and also the activities with the animero, while others solely attend the activities with the animero and see the Eucharist only as an offering to the souls, who in return are supposed to perform miracles.

Blurring of the boundaries between the popular and the institutional is not exclusive to Puerto Berrío, but is common in other Latin American countries as well. Jennifer Scheper, for instance, highlights that although popular religion may have a partial autonomy, it is not necessarily opposed to ecclesial religion:

In fact, in some contexts it is not possible to distinguish between popular religion and ecclesial religion. For example, priests may share in the local beliefs and practices of their parishioners, just as parishioners may incorporate traditional rites into their daily lives. We see this, for example, when priests lend their support to the celebration of locally significant patron saints or affirm local experiences of the miraculous. Also, community rituals and celebrations designed and organized completely by laypeople are often felt to be incomplete without the presence and benediction of clergy (Scheper 2016, p. 485).

The coexistence of different beliefs and practices is linked to two other important elements: the capacity to adapt to different traditions and the resignification of beliefs as a result of free interpretation, since "on the ground and in practice Catholicism has proven surprisingly expansive, inclusive, and adaptive. It is, in fact, stunningly pliant" (Scheper 2016, p. 480). This dynamic is also emphasized in the studies by Renée De la Torre in Mexico, in which esotericism, Catholicism, and New Age adapt to each other in such a way that the same set of beliefs produce new forms of religiosity with different meanings from each other (De la Torre 2012, 2013).

For example, De la Torre shows how some people can resignify beliefs from Eastern and New Age traditions and incorporate them in their own matrix of popular religiosity. Included in the data presented by de la Torre is the case of a woman who: 
performs Limpias [cleansing ${ }^{15}$ ] to harmonize the chakras, she lights incense sticks to 'scare away bad energy ${ }^{16}$, [...] and she appropriated the idea of karma but resiginifying it with the providentialist idea of destiny: 'Karma means that I was born to be screwed and I will continue to be screwed', [she says]. She detects neither conflict nor rupture between the knowledge of parapsychology and popular Catholicism, but rather it serves her to resume her activity as a healer (De la Torre 2013, p. 13).

In another example, De la Torre incorporates the case of a woman who, vice versa, reinterprets Catholic beliefs and rituals in terms of New Age meanings and communicates them to a group of followers both through workshops and meditation classes, and publically through a radio program:

'We must achieve the unity of the planet. Without distinction of religions or races, all beliefs lead us to the existence of the same God. We have to balance the energies of this planet to achieve harmony, to raise our level', [says the woman]. Both in her workshops and in her radio program, new age concepts are present in the signifiers of traditional Catholic devotion: The Virgin, the saints, the guardian angels, Christ, or God the father, all are spiritual guides. For her, the guides can present themselves under different forms and different personalities, but 'it's all the same' (De la Torre, 2012, p. 516).

Since popular Catholicism follows its own logic, it allows not only the emergence of new religious forms that differ from each other, but also results in a lack of internal homogeneity in terms of the different popular expressions underlying beliefs and practices, as will be shown in the following section.

\subsection{A heterogeneous religion}

Popular Catholicism has no canonical books that specify a body of teachings or precise instructions on how to proceed with rituals. Therefore, it is common that different beliefs circulate among the believers without a consensus. In Puerto Berrío, even though the animero offers some instructions, practical guidance and explanations for beliefs and ritual procedures, there are multiple versions about beliefs and practices constituting the cult. Some people, for example, say it is necessary to visit the cemetery during the whole month of November, while others claim that one only has to visit on Mondays. Some people, in addition to visiting the cemetery, deem it necessary to attend the Eucharist, and raise prayers for the souls of the deceased, whereas others consider praying at home to be enough. On the one hand, some people regularly attend the Eucharist — in the cemetery or in the parish-or pray and walk through the streets of the town in the night processions with the animero and,

15 The Spanish Limpia refers to a purification ritual using plants, some of them medicinal plants, in baths and fires, with the purpose of achieving protection from any danger, chasing away bad luck and getting rid of spells.

16 The original text in Spanish is "espantar las malas vibras" which can literally be translated as "scare away bad vibes". However, it can refer not only to a negative atmosphere, but also bad luck. Therefore, it is here translated as "scare away bad energy", which offers a wider scope. 
on the other, as the following interview excerpt illustrates, not every believer attends such processions or the Eucharist:

I don't really go to mass, I pray at home, but the usual, an Our Father when I go to bed to sleep (...), imagine, this town is famous because of the souls, and I don't even have the novena of the souls, I have never prayed the novena, and I am supposedly devoted to them (...) I don't know him, people say: the animero, the animero, but I have never seen him, nor do I know who he is, sometimes one hears the bell, but I don't pay attention to that (Interview. November 17th, 2019).

Another example of this heterogeneity is the ambiguity surrounding the cult of folk saints in the Central Cemetery of Bogotá, where different versions of the biography of such saints circulate, as in the case of the popular saint known as Salomé. This cult began in the 1950s at an uncared-for grave, which became well known for miracles attributed by the believers to this dead person, so much so that in a few years the tomb became a small sanctuary adorned with flowers and plaques of gratitude. Then one day a vendor of flowers, candles, and religious articles in the cemetery claimed, based on a portrait, that the person lying there was her mother, who was a peasant from the Colombian Andes, and her name was Salomé Muñoz (Bastidas et al. 2018). As time went by, other versions of this person's biography began to circulate, fueled by different details that helped to elaborate unfinished and fragmented accounts, so that people would circulate different versions, according to which she used to be:

(...) a prostitute, she used to sell candles in the cemetery, she used to wash other people's clothes, she used to live in the Egyptian neighborhood, in Perseverance neighborhood, was charitable, was a very poor woman, suffered in marriage, had a son who gave her a bad life, was beaten by her husband, was killed by her mother, died due to a sickness, was burned to death, was dragged to death, was mutilated ... ${ }^{17}$ (Peláez 1994, p. 155).

Although the vagueness and lack of knowledge regarding the biographies of folk saints $^{18}$ is generally attributed to the lack of historical data (Cortés 2007; Colatarci and Vidal 2008; San Juan 2010), such ambiguity also manifests even when the popular saint's biography is well documented, as in the case of the mathematician

\footnotetext{
17 In fact, the skeletal remains were moved to another cemetery in the south of the city, which resulted in the migration of a good part of the believers, who also built a small sanctuary. However, the cult at Salome's empty tomb still exists in the Central Cemetery, and some people are unaware that no one lies there. A person at the new sanctuary claimed that the one now known as Salome was her aunt and popularized a prayer with the image of a woman. As expected, new biographical versions began to circulate (Bastidas et al. 2018).

18 Other similar cases are those of Gauchito Gil in Argentina (Cortés 2007; Graziano 2007; Colatarci and Vidal 2008; San Juan 2010) and Jesús Malverde in Mexico (Flores and Gonzáles 2006; Cortés 2007).
} 
and engineer Julio Garavito ${ }^{19}$, who is buried in the same cemetery ${ }^{20}$. When inquiring about the life of this folk saint, people's responses varied and:

none of the believers gave an answer that came even minimally close to [the documented biography of the saint]. This was made clear by a sex worker (...)

"Today he is the one with the twenty thousand pesos bill, when he was alive, he was a writer, a poet, a person who helps, a womanizer, he enjoyed these women who practice prostitution" (Bastidas et al. 2018, p. 67).

Regardless of the ambiguities, people tend to invest hope for the resolution to urgent problems in the supposed earthly intervention of supernatural beings, such as the souls of the deceased, which will be addressed in the following section.

\subsection{A utilitarian religion}

Unlike Catholicism, which promotes the performance of good works through a promise of salvation in the hereafter, popular Catholicism is characterized by a focus on seeking relief from the most urgent worldly needs. This can, among others, be seen through two features: the strong presence among the poor population ${ }^{21}$ and the performance of some magic rituals.

In 2019, according to the indicator of unsatisfied basic needs, $38 \%$ of the population of Puerto Berrío lived in poverty (Torres et al. 2020). This corresponds to the socio-economic situation of the people in Magdalena Medio, which historically is "one of the poorest regions with high rates of violence. Poverty becomes evident when one considers that, except for Barrancabermeja ${ }^{22}$, all the municipalities in the region have indices that show more than $60 \%$ of their inhabitants in poverty" (Dávila 2009, p. 26).

Such situation could hypothetically be one reason as to why in Puerto Berrío the devotees interviewed included in their list of petitions to the souls the fulfillment of material needs. Interviewees commonly ask the souls for help in solving a wide range of problems, such as finding a job or a better job, securing admission to a public university ${ }^{23}$, finding a cure for an illness, winning prizes in gambling houses or in getting a house. According to Christian Parker, people who adhere to popular Catholicism in Latin America ask for the resolution of "daily problems of the subordinate classes: work, health, affective and family relations, studies, etc.

\footnotetext{
19 Julio Garavito was a Colombian scientist who lived between 1865 and 1920 in Bogotá. For his outstanding contribution to Colombian astronomy his image appeared on the old twenty-thousand-peso bill and the International Astronomical Union named a crater on the moon after him (Bastidas et al. 2018).

20 The same happens with the folk cult of official saints, whose biographies are completely unknown to believers, despite the existence of the respective hagiographies.

21 Other religious expression with a strong presence in the lower economic classes is Pentecostalism, see Lalive d'Epinay (2010) and Beltrán (2013).

22 With approximately 210,000 inhabitants, Barrancabermeja is the largest city in the Magdalena Medio region.

23 In Colombia, the access to public university education is restricted and high-quality private university education, due to the high costs, is not within the reach of socio-economically poor people.
} 
These are requests of the devotees linked to universal problems that the popular culture faces ${ }^{24}$ " (Parker 1993, p. 182).

In Puerto Berrío, as usually happens in other cases of popular Catholicism, people also often ask for the souls to help with relationship matters, such as the solution to problems in their relationships, the resolution of a personal conflict, or the retrieval of a loved one whose whereabouts are unknown. But people also enlist the souls in matters related to behaviors or actions that are generally disapproved of socially, such as the commission of crimes. This orientation of popular Catholicism is also present in other cases from Latin American countries: in Argentina, for example, where the cult of San la Muerte ${ }^{25}$ (Saint the Death) also holds "a form of veneration (...) in which the saint is used for evil, he is asked for 'damages' or changes in unfavorable situations through death or illness" (Calzato 2008b, p. 275), or the cult of Jesus Malverde in Mexico, which is known for having among its devotees persons linked to drug trafficking as well as criminal delinquency (Gerardo and Jungwon 2014).

The presence of popular Catholicism among the less fortunate classes has also been identified in other specific cases in Colombia and other Latin American countries. Examples include the devotion to folk saints in the Central Cemetery of Bogotá among the inhabitants of the Santa Fe neighborhood, especially among transgender sex workers (Bastidas et al. 2018), the cult of San Luis Rey and Santa Muerte (Saint Death) in México (Fragoso 2011; Gonzáles 2014; Gutiérrez 2015), and the cult of San La Muerte (Saint the Death) (Calzato 2008a, b) and the Gauchito Gil in Argentina (San Juan 2010). For this reason, some scholars distinguish among the possible connotations of the Spanish term popular which identifies it with the religion of the poor $^{26}$ (Peterson 1998; Martín 2009; De la Torre and Martín 2016; Scheper 2016).

In Puerto Berrío, the satisfaction of such aforementioned needs is sought through rituals whose purpose is to influence the will of the souls so that they offer their help. In this context, the best-known practice is the adoption of NN bodies found floating in the Magdalena River. For years, the inhabitants of the town observed how several times a week bodies of people murdered in municipalities further up the river appeared, which were then rescued by the town's fishermen, and buried as unidentified persons in the local cemetery. Faced with this situation, the practice of praying, naming the unidentified body, and the maintenance of a clean and sometimes decorated grave in exchange for a miracle, became widespread. Some people

\footnotetext{
${ }^{24}$ Christian Parker calls popular culture "the broad cultural production [habits, customs, ways of thinking] of the subaltern classes and groups of society" (Parker 1993, p. 58), that is, the culture of working-class people and peasants. In this sense, it is worth noting that the adjective popular is often used to label this type of religion as the religion of the poor (Scheper 2016). However, the term popular is also often understood as something that comes from the people, without emphasizing socio-economic conditions (Graziano 2007).

25 Here it is important to clarify that the cult of death personified as a saint takes place both in Argentina, where it is called San La Muerte (Saint the Death), and in Mexico, where it is known as the Santa Muerte (Saint Death). Regarding this, see Hernández (2017).

26 In Spanish, the word popular has more than one meaning. It could be understood as something related to the working-class people, as something well known or famous, and something that culturally emerges from people in general and belongs to them, such as artistic expressions or, in this case, religious expressions, which are usually translated into English as folk.
} 
promised to attend the Eucharist, others promised to pray with the animero, and yet others combined these with promises of daily visits to the cemetery. Considering that the people found in the river were predominantly victims of forced disappearance, devotees believe that, since relatives and acquaintances do not know they are dead, nobody prays for them. Hence, the nameless souls are more in need of prayers than others and, therefore, more effective in granting miracles.

One of the most common offerings is the recognition of the miracle through plaques of gratitude that believers leave on tombs converted into altars. Generally, people give thanks for a favor by referencing the date it occurred on a marble or stone plaque that is left as a public testimony to the miraculous event ${ }^{27}$. In daily interactions, people either communicate to others the process of achieving such results, or the animero explains the proper set of practices for such purpose, when people need advice in this regard.

\section{Conclusion}

The Colombian souls cult we observed in Puerto Berrío is a clear expression of what we propose to term as 'popular Catholicism'. From the perspective of sociological theory of religion, this version of religion, situated at the intersection of institutionalized religion and non-institutionalized religious practices, is particularly interesting. Popular Catholicism has a structurally ambiguous relation to institutional Catholicism. On the one hand, many of its practices and their underlying meaningfulness, as well as lack of negative sanctions, can be regarded as being in strong contrast, if not direct contradiction, to established church religion. On the other hand, even though this tension comes to the fore in practical and doctrinal terms, there is hardly any expressed antagonism of the two forms of religion.

Clearly, Catholic sanctity, around which the souls-cult is formed, is a highly regulated form of religious practice, both in terms of its establishment through a set of carefully controlled legal canonical procedures and in the regulations regarding proper worship that result from this process. In these ways, popular religion breaks away from the regulatory framework of the saint as a salvation good as well as from the power structure underlying it. It does so, however, while leaving intact the relationship between saints and their worshippers as well as the underlying rationale for entering into this relationship. The saint worshipping practices we observed can, therefore, be described as partial negations of Catholic practice, since they wrest authority over worshipper-saint relations from the regulating force of the Church, while leaving their structure and purpose largely intact.

In addition, Popular Catholicism uses the symbolic structure of official Catholicism as a useful resource for the maintenance of its validity. Popular Catholicism

\footnotetext{
27 This practice is not exclusive to the believers of Puerto Berrío but is in fact quite common in the cult of folk saints. Other forms of acknowledging the miracle, for example, can be observed in the case of the cult of Jesus Malverde in Mexico, where believers express their gratitude through images, ex-votos, poems, and songs, such as corridos, a typical musical genre of Mexican popular culture (Flores and Gonzáles 2006, 2007).
} 
takes the elements of official worship, such as prayers and the Eucharist, and uses them as a link to a new structure of beliefs and practices. Although, traditionally, the popular has been defined in opposition to the official, we argue that such opposition rests on the denial of institutional authority, but not necessarily in symbolic terms, although it is empirically verifiable that the church can also capitalize on elements of popular worship. However, this is a matter that transcends the limits of the discussion in this article.

Nonetheless, the release of this and other practices from institutional oversight brings with it considerable variation in terms of legitimate interpretations and even resignification of beliefs, and enables popular religion to adapt to different institutional and popular traditions, as well as the variety of individual life circumstances among its adherents.

We find a similar limited difference between popular religion and church religion when it comes to the former's "utilitarian logic" that underlies many of the practices described above. Generally, its adherents pursue rationally weighted ends in the form of miracles or favors that occur in the earthly realm and not a promise of salvation in the hereafter-since popular Catholicism does not stimulate salvation and well-being as a product of good works rewarded by God. This lends popular religion a decidedly magical character. This aspect is closely linked to the conspicuous absence of the concept of $\sin$ and transcendental retribution for faulty behavior. The negative side of the salvation economy is also transferred to this world in that faults and failure do exist in individuals, but they become relevant only as factors limiting or disturbing the innerworldly transactions set in motion through magical manipulation.

Both the "utilitarian logic" and the absence of negative religious sanctions repeat the pattern described above with regard to the worshipping of saints: They differ markedly from established church religious practice and doctrine, while not being so completely different as to render the religious beliefs and practices we observed a new form of religion. Means-ends rationality does exist in a sanctioned form within Catholicism, and the individual shortcomings that might prevent the establishment of a magical transaction in popular Catholicism are treated by institutional Catholicism as well, albeit in form of a transcendental relation that endows the priest with the power to regulate this relation through the granting and denying of salvation goods.

So there is kinship between popular religion and church religion, and we contend that it is demonstrated particularly well by the absence of overt criticism or contradiction of Catholic doctrine, practice, and institutional power as well as the formal and informal acts of legitimation that the animero receives from priests.

With this case we have brought to the fore a definitely more peaceful relationship between church and popular religion as usually associated with Latin America, that being the cradle of Liberation Theology with a long history of a highly tense and conflict laden relationship between lay believers and church hierarchy. Although the results may be generalizable for other world regions, they may serve as point of comparison for the ongoing process of religious change in countries of different world regions.

Acknowledgements This article is a part of the doctoral project of Luis Bastidas Meneses, funded by DAAD Research Grant for Doctoral Students 91686744. We owe special gratitude to the inhabitants of Puerto Berrío, Colombia, for their generous fieldwork participation through talks and interviews, and by 
providing relevant information and documents. We also thank Rob Glaser and Eileen Jahn for their comments on the text.

Funding Open Access funding enabled and organized by Projekt DEAL.

Open Access This article is licensed under a Creative Commons Attribution 4.0 International License, which permits use, sharing, adaptation, distribution and reproduction in any medium or format, as long as you give appropriate credit to the original author(s) and the source, provide a link to the Creative Commons licence, and indicate if changes were made. The images or other third party material in this article are included in the article's Creative Commons licence, unless indicated otherwise in a credit line to the material. If material is not included in the article's Creative Commons licence and your intended use is not permitted by statutory regulation or exceeds the permitted use, you will need to obtain permission directly from the copyright holder. To view a copy of this licence, visit http://creativecommons.org/licenses/by/4.0/.

\section{References}

Andrade, S. 2004. Protestantismo indigena. Procesos de conversión religiosa en la provincia de Chimborazo. Quito: Ediciones Abya-Yala; Instituto Francés de Estudios Andinos IFEA; Facultad Latinoamericana de Ciencias Sociales FLACSO, sede Ecuador.

Arias, R. 2003. El episcopado colombiano: intransigencia y laicidad (1850-2000). Bogotá: Universidad de los Andes \& ICANH.

Arias Toapanta, F.F. 2017. Memoria histórica y prácticas comunicativas de la tradición "el Animero”, en la parroquia de Bayushig provincia de Chimborazo. Bachelor Thesis. Quito: Faculty of Social Sciences and Human Behavior, Universidad Politécnica Salesiana. https://dspace.ups.edu.ec/bitstream/ 123456789/13568/6/UPS-QT11439.pdf.

Bastidas, L. 2015. Militancia y filiación religiosa en el Movimiento Político MIRA. Master Thesis. Bogotá: Department of Sociology, Universidad Nacional de Colombia. http://bdigital.unal.edu.co/49142/.

Bastidas, L., D. Díaz, and V. Villamarín. 2018. Entre la calle y el cementerio. Prácticas, rituales y religiosidad de las trabajadoras sexuales transgénero del barrio Santa Fe. Bogotá: Pontificia Universidad Javeriana.

Beltrán, W. 2012. Descripción Cuantitativa de la Pluralización Religiosa en Colombia. https://revistas. javeriana.edu.co/index.php/univhumanistica/article/view/3636. Accessed 15 Apr 2021.

Beltrán, W. 2013. Del Monopolio Católico a la Explosión Pentecostal. Pluralización Religiosa, Secularización y Cambio Social en Colombia. Bogotá: Universidad Nacional de Colombia.

Beltrán, W., and S. Larrota. 2020. Diversidad Religiosa, Valores y Participación Política en Colombia. Resultados de la Encuesta Nacional Sobre Diversidad Religiosa 2019. Bogotá: Act Iglesia Sueca, Comisión Intereclesial de Justicia y Paz, World Vision-Colombia, Universidad Nacional de Colombia.

Beltrán, W., and J. Quiroga. 2017. Pentecostalismo y política electoral en Colombia (1991-2014). Colombia Internacional https://doi.org/10.7440/colombiaint91.2017.06.

Berger, P. 1990. The sacred canopy. Elements of a sociological theory of religion. New York: Anchor Books.

Bustamante, F., and F. Orellana. 2020. Del Monopolio Católico al Establecimiento del Pentecostalismo: Cambios en el Cristianismo Latinoamericano Desde la Segunda Mitad del Siglo XX. Intelligere, Revista de História Intelectual https://doi.org/10.11606/issn.2447-9020.intelligere.2020.173649.

Calzato, W. 2008a. San La Muerte (Argentina). Devoción y existencia. Entre los dioses y el abandono. LiminaR. Estudios sociales y humanísticos 6(I):26-39. http://www.scielo.org.mx/pdf/liminar/v6n1/ v6n1a3.pdf.

Calzato, W. 2008b. "Al santo hay que cumplirle". Castigo y devoción San la Muerte/San Baltasar (Argentina). Itinerarios 8:269-284. http://itinerarios.uw.edu.pl/wp-content/uploads/2014/12/14_calzato. pdf.

CNMH. 2016. Basta ya! Colombia: memories of war and dignity. General Report. Bogotá: Centro Nacional de Memoria Histórica. http://centrodememoriahistorica.gov.co/descargas/informes2016/bastaya-ingles/BASTA-YA-ingles.pdf.

Colatarci, M.A., and R. Vidal. 2008. Entre las devociones populares y el culto a los muertos en el paisaje ritual. LiminaR. Estudios Sociales y Humanísticos VI(2):128-141. https://doi.org/10.29043/liminar. v6i2.287. 
Cortés, S. 2007. De facineroso ladrón a santo milagroso: el culto a los bandidos en la literatura y la devoción popular. Caravelle 88:11-29. https://doi.org/10.3406/carav.2007.3135.

Dávila, A. 2009. La violencia en el Magdalena Medio. Análisis de la dinámica espacial. Bogotá: Universidad de los Andes.

De la Torre, R. 2012. La Religiosidad Popular Como "Entre-medio" Entre la Religión Institucional y la Espiritualidad Individualizada. Civitas- Revista de Ciências 12(3):506-521. https://doi.org/10.15448/ 1984-7289.2012.3.13013.

De la Torre, R. 2013. La Religiosidad Popular. Encrucijada de las Nuevas Formas de la Religiosidad Contemporánea y la Tradición (el Caso de México). Ponto Urbe https://doi.org/10.4000/pontourbe. 581.

De la Torre, R., and E. Martín. 2016. Religious studies in Latin America. The Annual Review of Sociology 42:1-20.

De Roux, R. 1983. Una Iglesia en estado de alerta: Funciones sociales y funcionamiento del catolicismo colombiano: 1930-1980. Bogotá: Servicio Colombiano de Comunicación Social.

Delgado, J. 1991. Sucesos de la historia de El Salvador, volumen I: Introducción a la historia en El Salvador (1521-1821). San Salvador: Archdiocese of San Salvador.

Di Stefano, R. 2013. Reflexiones de los autores sobre el dossier. Corpus 3(2):2-23.

Duque, J. 2010. Las comunidades religiosas protestantes y su tránsito hacia lo político-electoral en Colombia, 1990-2007. Revista Mexicana de Sociología 72(1):73-111. https://www.jstor.org/stable/ 25677032.

Flores, E., and R. Gonzáles. 2006. Jesús Malverde: plegarias y corridos. Revista de literaturas populares 6(1):32-60. https://dialnet.unirioja.es/servlet/articulo?codigo=2219161.

Flores, E., and R. Gonzáles. 2007. Malverde. exvotos y corridos (en las voces de cantores sinaloenses). Caravelle. Cahiers du monde hispanique et luso-brésilien 88:111-138. https://www.persee.fr/doc/ carav_1147-6753_2007_num_88_1_3140.

Fragoso, P. 2011. De la "calavera domada" a la subversión santificada. La santa muerte, un nuevo imaginario religioso en México. El cotidiano 169:4-16. https:/www.redalyc.org/articulo.oa? $\mathrm{id}=32519776002$.

Frigerio, A. 2007. Repensando el monopolio religioso del catolicismo en la Argentina. In Ciencias sociales y religión en América Latina, ed. M.J. Carozzi, C. Ceriani Cernadas, 87-118. Buenos Aires: Biblos \& ACSRM.

Frigerio, A. 2013. Nuestra elusiva diversidad religiosa: Cuestionando categorías y presupuestos teóricos. Corpus 3(2):1-7. http://corpusarchivos.revues.org/313.

Frigerio, A. 2018. Por qué no podemos ver la diversidad religiosa? Cuestionando el paradigma católicocéntrico en el estudio de la religión en Latinoamérica. Cultura y representaciones sociales 12(24): 51-95. https://doi.org/10.28965/2018-024-03.

Frigerio, A., and H. Wynarczyk. 2013. La diversidad religiosa en Argentina: Un desafío a la ciencia normal. Religión y Cultura 6(1):3-9. https://www.revistaculturayreligion.cl/index.php/revistaculturayreligion/ article/view/324.

Gerardo, G., and P. Jungwon. 2014. The cult of Jesús Malverde: crime and sanctity as elements of a heterogeneous modernity. Latin American Perspectives 41(2):202-214. https://www.jstor.org/stable/ 24575507. Accessed 20 Jul 2020.

Gonzáles, D. 2014. Culto y festividad a San Luis Rey en la colonia El Ajuso: un testimonio de religiosidad popular en la ciudad de México. Relaciones. Estudios de historia y sociedad 35(139):233-254. http:// www.scielo.org.mx/pdf/rz/v35n139/v35n139a10.pdf.

Graziano, F. 2007. Cultures of devotion. New York: Oxford University Press.

Gutiérrez, A. 2015. Etnografía del culto a la Santa Muerte en San Cristobal de las casas, Chiapas. Quehacer científico en Chiapas 10:80-90.

Gutiérrez, F. 2020. ¿Un nuevo ciclo de la guerra en Colombia? Bogotá: Debate.

Haken, M. 2020. Celebrations: religious events beyond the dichotomy of individualization and communitization. The Cultural Bias of Religiosity: Concepts, Measurements, and Results From Non-Western Perspectives. Special Issue: Journal of Empirical Theology 33(1):100-121.

Hernández, A. (ed.). 2017. La Santa Muerte: espacios, cultos y devociones. Tijuana, San Luis Potosí: El Colegio de la Frontera Norte, El Colegio de San Luis.

Hervieu-Léger, D. 2005. La religión, hilo de la memoria. Barcelona: Herder. M. Solana, Trans.

Isambert, F.-A. 1982. Le sens du sacré: Fête et religion populaire. Paris: Presses Universitaires de France.

Knoblauch, H. 2008. Spirituality and popular religion in Europe. In Secularization. The comparative sociology of de-secularization, Vol. IV, ed. B. Turner, 343-354. London: SAGE. 
Knoblauch, H. 2009. Populäre Religion. Auf dem Weg in eine Spirituelle Gesellschaft. Frankfurt, New York: Campus.

Knoblauch, H. 2014. The communicative construction of transcendence: a new approach to popular religion. In Religion, tradition and the popular, ed. J. Schlehe, E. Sandkühler, 29-49. Bielefeld: transcript.

Lalive d'Epinay, C. 2010. El refugio de las masas. Estudio sociológico del protestantismo chileno. Santiago de Chile: Instituto de Estudios Avanzados Universidad de Santiago de Chile \& Centro Evangélico de Estudios Pentecostales.

Losonczy, A.-M. 2001. Santificación popular de los muertos en cementerios urbanos colombianos. Revista Colombiana de Antropología 37:6-23.

Luckmann, T. 1967. The invisible religion. New York: MacMillan.

Martín, E. 2009. From popular religion to practices of sacralization: approaches for a conceptual discussion. Social Compass 56(2):273-285.

Marzal, M. 1993. Sincretismo y mundo andino: un puente con el otro. In La formación del otro De palabra y obra en el nuevo mundo, Vol. 3, ed. G. Gary, J.K. de Alva, M. León-Portilla, and M. Manuel Gutiérrez, 231-250. Madrid: Siglo XXI.

Marzal, M. 2002. Tierra Encantada. Tratado de Antropología Religiosa de América Latina. Madrid: Editorial Trotta, Pontificia Universidad Católica del Perú.

McGuire, M.B. 2008. Lived religion. Faith and practice in everyday life. New York: Oxford University Press.

Ortega, B. 2018. Evangélicos y política. Formación y viabilidad de los partidos políticos evangélicos en Colombia (1990-2018). Ph.D. Dissertation. Bogotá: Department of Political Science. Universidad de los Andes.

Parker, C. 1993. Otra lógica en América Latina. Religión popular y modernización capitalista. Santiago: Fondo de Cultura Económica.

Peláez, G.I. 1994. Magia, religión y mito en el Cementerio Central de Santafé de Bogotá. In Pobladores urbanos: en busca de identidad, ed. J. Arturo, 147-160. Bogotá: Tercer Mundo Editores, ICANColcultura.

Peterson, A. 1998. Varieties of popular catholicism: a parish study. Social Compass 45(3):399-415.

Possamai, A. 2005. Religion and popular culture: a hyper-real statement. Brussels: Peter Lang.

Roman Catholic Church. 2003. La Santa Sede. http://www.vatican.va/archive/ENG0015/_P2N.HTM\# \$1BZ. Accessed 5 Oct 2020.

Romero, M. 2003. Paramilitares y autodefensas 1982-2003. Bogotá, D.C.: Instituto de Estudios Políticos y Relaciones Internacionales (IEPRI), Editorial Planeta.

San Juan, C.F. 2010. La santidad popular de los bandidos. El culto al Gauchito Gil. Tesis de Maestría. México: Universidad Nacional Autónoma de México, Programa de posgrado en Estudios Latinoamericanos. https://repositorio.unam.mx/contenidos/la-santidad-popular-de-los-bandidos-el-culto-algauchito-gil-426963?c=pQ8wXB\&d=false \&q=gauchito\%20gil $\& \mathrm{i}=1 \& \mathrm{v}=0 \& \mathrm{t}=$ search_0\&as=0.

Sanchis, P. 2001. Religiões, religião: alguns problemas do sincretismo no campo religioso brasileiro. In Fiéis \& cidadãos : percursos de sincretismo no Brasil, ed. P. Sanchis, B.T. Figueirôa de Medeiros, 9-57. Rio de Janeiro: UERJ.

Scheper, J. 2016. Contemporary popular Catholicism in Latin America. In The Cambridge history of religions in Latin America, ed. V. Garrard-Burnett, P. Freston, and S.C. Dove, 480-490. New York: Cambridge Universuty Press. https://doi.org/10.1017/CHO9781139032698.031.

Thompson, L.J. 2005. Establishment and growth of protestantism in Colombia. Ph.D. Dissertation. Bangor: School of Education. University of Wales.

Torres, E., J. Torres, M. López, O. Loaiza, and C. Sánchez. 2020. Puerto Berrío. Guía Base para la Reactivación Económica. https://www.udea.edu.co/wps/portal/udea/web/generales/interna/!ut/p/z0/ fY7LCsIwEEV_RRddlsQqPpaliCCuFESzkXEadTRNqknEz3dSUHDjKnOZM-dGKLETysKTzhDI WTCc92p8mM6qY1CO5GqxXlayHFflfLLZroppIZZC_QfYQNf7XZVCobNBv4LYte4RwMRaQyb B_6aLa_RnJusDhYjdXzIZLdVQa58D8tMQgk_UCTCakBaZRNIWCXxPc1kfh_3j8Mt19axwXTLk -cZ18hyZzxuWI7VgWF_r_KEBAz0hVefJ5ZJGtDe1fwNvBnTO/. Accessed 10 May 2021.

UN Human Rights. 2021. International convention for the protection of all persons from enforced disappearance. https://www.ohchr.org/EN/HRBodies/CED/Pages/ConventionCED.aspx. Accessed $20 \mathrm{Jul}$ 2021.

Veloz Rios, M. 2017. La identidad iconográfica del animero de Penipe y su incidencia cultural en los habitantes de la cabecera cantonal de 18 a 30 años en el periodo Junio-diciembre 2016. Bachelor Thesis. Riobamba: Faculty of Political and Administrative Sciences, Universidad Nacional de Chimborazo. http://dspace.unach.edu.ec/bitstream/51000/4384/1/UNACH-EC-FCP-COM-SOC-2017-0043.pdf. 
Vignolo, P. 2013. ¿Quién gobierna la ciudad de los muertos? Políticas de la memoria y desarrollo urbano en Bogotá. Memoria y sociedad 35(17):125-142. 